On the path to differentiation

Upward transfer, logic of variation and sub-optimality in EU social policy

Martinsen, Dorte Sindbjerg; Uygur, Ayca

Published in:

Journal of European Public Policy

DOI:

10.1080/13501763.2014.923020

Publication date:

2014

Document version

Early version, also known as pre-print

Citation for published version (APA):

Martinsen, D. S., \& Uygur, A. (2014). On the path to differentiation: Upward transfer, logic of variation and suboptimality in EU social policy. Journal of European Public Policy, 21(9), 1255-1272.

https://doi.org/10.1080/13501763.2014.923020 


\title{
On the path to differentiation: upward transfer, logic of variation and sub- optimality in EU social policy
}

\author{
Dorte Sindbjerg Martinsen and Ayca Uygur Wessel \\ Journal of European Public Policy (2014) 21:9, pp. 1255-1272 \\ http://www.tandfonline.com/doi/abs/10.1080/13501763.2014.923020?queryID=\%24\%7BresultBean.q
}

$\underline{\text { ueryID\%7D\#.U_H2 L } L C C S 70}$

\begin{abstract}
Studies of the upward transfer of power to European Union (EU) institutions have long focused on how integration is progressed. However, the burgeoning literature on differentiation has brought flexibility and variation into the picture. This paper aims to add to this strand of literature by examining the 'path to differentiation' within EU working time regulation as it has unfolded over time. It identifies the 'opt-out' as a means of differentiation adopted to overcome policy deadlocks within collective decision-making, albeit one with unforeseen consequences. In particular, the paper investigates the causes and effects of differentiation by examining 1) its origin, 2) the 'logic of variation' or 'opt-out spiral' that spurs differentiation and 3) the implications of differentiation over time. The paper concludes that differentiation has dynamic and broad consequences that are likely to produce suboptimal policy outcomes and a decline in integration over time.
\end{abstract}


Keywords: differentiated integration, logic of variation, opt-out spiral, EU social policy, Working Time Directive 


\section{Introduction}

Upward transfer is one of the key concepts for understanding the dynamics of European integration (Jensen et al. 2014, this volume). However, upward transfer is often met with resistance, and more recent contributions to this literature particularly emphasise the importance of differentiation in European integration. Differentiated integration refers to cases in which 'the territorial extension of European Union (EU) membership and EU rule validity are incongruent' (Holzinger and Schimmelfennig 2012: 292), and it arises as a result of variation in the types and scopes of upward transfer in different member states and across policies. The conventional explanation is that greater heterogeneity among the member states and a broadened functional scope of EU regulation have caused differentiation to rise and to become increasingly visible across EU policies since the second half of the 1990s (Holzinger and Schimmelfennig 2012: 299; Leuffen et al. 2013: 21).

This paper examines the processes of upward transfer and differentiated integration in the EU's working time regulation as it has unfolded over time. It identifies the 'optout' as a means of differentiation that was adopted to overcome policy deadlocks within collective decision-making, albeit one with unforeseen consequences. In particular, the paper investigates the causes and effects of differentiation by examining 1) its origin, 2) the 'logic of variation' or 'opt-out spiral' that spurs differentiation and 3) its implications for integration over time. The paper thus engages in the processes and effects of variation in secondary legislation, as called for by the burgeoning literature on differentiated integration (Holzinger and Schimmelfennig 2012; Leuffen et al. 2013). EU working time constitutes a key part of 'Social Europe', where exemptions, special rules and opt-outs have existed for many 
years. The logic of variation identified in EU social policy provides an example of how providing an exception to the general rule to overcome a specific joint decision trap has unforeseen yet major implications for forthcoming decision-making as well as for implementation and compliance in this regulatory field.

The opt-out constitutes our operationalisation of differentiated integration because, when it is activated, the opt-out mechanism creates a de facto incongruence between the spatial extent of the EU and its jurisdiction. In a process of upward transfer, the opt-out serves two purposes. On the one hand, it serves a collective purpose, constituting a mechanism by which a joint decision trap may be overcome because a potential veto actor may agree on a common position if granted an exception from the general rule (Scharpf 2006: 857-858). On the other hand, the opt-out serves domestic purposes, serving as a mechanism for the member states to protect their national sovereignties. ${ }^{1}$

The regulation of working time is a policy field of high political salience, as are most other parts of EU social policy. The Working Time Directive (WTD) was first adopted in $1993^{2}$ and aims to improve worker health and safety by setting minimum standards for organising working time. The EU regulation within the field is thus one of market correction and one that constitutes an important part of social Europe. In short, the Directive corrects the market by establishing a maximum of a 48-hour work week on average within a reference period of four months, with minimum daily and weekly rest periods and a minimum of 4 weeks of paid leave per year.

\footnotetext{
${ }^{1}$ The work of Adler-Nissen provides more general insights on the opt-out as an instrument to protect and manage the quest for national sovereignty; see Adler-Nissen $(2008,2011)$.

2 The Council Directive 93/104/EC of 23 November 1993 concerns certain aspects of the organisation of working time.
} 
The process of upward transfer has created strong positions for the EU's institutions - i.e., the European Commission (EC), the Court of Justice of the European Union (CJEU), the European Parliament (EP), member states and their social partners. The EU's regulation of working time thus involves multiple actors and institutions with distinct positions and preferences who are all seeking to control the process of upward transfer (Jensen et al. 2014). Upward transfer therefore constitutes an interesting case for examining the tensions and dynamics that unfold when EU competences are extended 1) between EU institutions and member states' positions; 2) between the EU triangle of the Commission, Court and Parliament; and 3) between the EU's social partners.

We consider the historical institutionalist framework for examining the theoretical process of upward transfer and contestation over time, but we find that it is inadequate for explaining nonlinear integration processes in which the logic of increasing returns does not apply. The paper is structured as follows. Section 2 below presents the theoretical framework, data and method. Section 3 conducts the analysis of EU working time regulation over time and identifies the causes, dynamics and effects of differentiation on the secondary legislation of EU social policy. Section 4 provides concluding remarks on the identified 'path to differentiation'.

\section{On Upward Transfer and Differentiated Integration}

'Differentiated integration' defines a situation in which some rules apply to a subset of member states alone, whereas other rules may also apply to non-members (Holzinger and Schimmelfennig 2012: 292). Thus, it characterises a Union that, through processes of upward transfer, has developed a core but at the same time 
whose levels of centralisation and territorial extension vary by function (Leuffen et al. 2013: 10). Based on the burgeoning literature on differentiated integration, the causes and effects of this variation have only been vaguely examined on theoretical terms, and empiricists tend to have concentrated on a small number of significant cases of primary law (Holzinger and Schimmelfennig 2012: 293; Leuffen et al. 2013). ${ }^{3}$ This paper seeks to address this gap and explores how differentiated integration may be reflected in EU secondary law.

Integration theories have foremost presented upward transfer from member states to the European Union as a forward and linear move - albeit sometimes slow and cumbersome. The battles between the theories on EU cooperation have aimed to explain why and how integration has occurred. However, both the treaty reforms and the daily decision-making processes of the EU have increasingly come to produce the institutional side effect of differentiated integration, which integration theories generally seem ill-equipped to explain. Processes of upward transfer that could gradually lead to decreased integration have not caught the attention of integration theories.

Historical institutionalism stands out as the suitable frame for scholars who focus on policy processes as they unfold over time and who attribute a vital role to institutions in these processes. Applied to the study of EU policy processes, this institutionalism identifies a 'path to European integration' (Pierson 1996). According to Pierson's (1996: 144-148) seminal argument, the initial steps of European integration will bring about more integration because it will be much costlier for the member states to extricate themselves from an arrangement than to invest in one. Resistant

\footnotetext{
${ }^{3}$ See also Stubb 1996; Egeberg and Trondal 1999 for some of the earlier work on differentiated integration.
} 
supranational actors, unintended consequences of action and sunk costs all contribute to the linear course of European integration (Pierson 1996: 131-148). What is of great importance here are contingency effects, which arise through the unforeseen yet strong impact of 'earlier events', and institutional inertia, whereby 'positive feedback effects' ensure the stickiness of the institutional structures that are already in place (Pierson 2000: 263). Hence, such mechanisms ensure that, after the initial steps of European institutions and polity building, European integration will develop its own logic of 'increasing returns', thereby evolving in a path-dependent fashion that would favour an 'ever closer union' (Pierson 2000: 263).

However, in an EU that is integrated in a differentiated fashion, forces of integration and contestation are expected to work in a more complex way. Differentiated integration opens up the possibility that the feedback mechanisms that characterise the logic of increasing returns may not always have an integrative effect. Feedback mechanisms are likely to dominate the interaction between forces of integration and forces of contestation as well. This contestation occurs along both a horizontal axis, on which the EU's own inter-institutional dynamics come to the fore, and a vertical one, as EU institutions, member states and other relevant political actors respond to policy developments that are jointly created. In this sense, EU institutions are not expected to act uniformly regarding a question of integration given that the $\mathrm{EC}$, the CJEU and the EP work through very different mechanisms. Furthermore, their decisions relate to member states and other relevant actors in distinct ways, often involving unintended consequences and influencing their positions.

For the regulation of contested issue areas, such as social policy, we thus question why contingency effects and institutional inertia should guarantee a logic of 
increasing returns that will necessarily push for further integration. We hypothesise that differentiation created at the initial stages of reform might develop a logic of variation instead of one of increasing returns. We further hypothesise that, when such a logic of variation is at work, the policy process might result not only in further differentiation through mechanisms of emulation but also in 'sub-optimality' in the sense that policy outcome no longer serves the purpose for which it was originally implemented. In the seminal work of Scharpf, the 'joint-decision trap of EU collective decision making tends to generate sub-optimal policy outcomes' (Scharpf 1988). Suboptimality occurs and extends when the development of a policy instrument diverges from its general aim and principles, allowing for heterogeneous application and lowering the common denominator of a regulatory text.

Following our operationalisation of differentiation as the opt-out, we conceptualise the logic of variation as an opt-out spiral whereby the opt-out mechanism loses its integrative function of 'getting the awkward partner on board' but is emulated by other parties as a way of counteracting integrative forces, ultimately resulting in even further differentiated and possibly suboptimal policy outcomes, as explored below.

Opt-outs; differentiation in concrete terms

Opt-outs and other forms of exceptions that are conducive to member-state flexibility are generally accepted as some of the most effective consensus-promoting mechanisms in the European integration literature (Falkner 2011: 12; Trauner 2011). In EU politics, a wide range of flexibility is at the disposal of the decision-makers to establish compromises. These instruments of flexibility may all generate a logic of variation in EU integration. Member states may be granted temporal or permanent 
opt-outs. Sectorial exemptions may be adopted into a regulatory text. Derogations from the general rule may be inserted as articles and so forth. By providing a larger and more flexible space in which the member state governments can manoeuvre, exceptions can indeed provide a way out of a joint decision trap. The opt-out is one such exception that a member state may request and other member states may be willing to grant to overcome a policy deadlock, even as they accept differentiation (Holzinger and Schimmelfennig 2012: 299). Especially concerning issue areas in which political salience is relatively high and when very divergent national points of view characterise the negotiations, legislation with the possibility of opting out might be considered to be more beneficial compared with no legislation at all for the majority of stake holders. The importance of opt-outs is well known within treaty law (Adler-Nissen 2008, 2011; Dyson and Marcussen 2010; Trauner 2011). However, opt-outs have also been used successfully in secondary law-for example, in the area of environmental policy, in which negotiators have avoided the risk of veto by providing particular exceptions or the possibility of derogations (Holzinger 2011: 122-123). The findings in the analysis below are thus not likely to be particular to the social policy area but to have a wider reach with regard to the causes, dynamics and effects of decision making when exceptions are permitted. Such exceptions are likely to give way to a 'multi-speed Europe' where countries can choose to be integrated into the European unit as much as their 'political sensitivities' permit them (Scharpf 2006: 857-858). We thus claim that the theoretical and empirical findings of the analysis conducted below have certain generalisability for other policy areas in which exemptions or opt-outs are granted to stimulate the integration process.

Whereas opt-outs are considered to be beneficial for EU legislation to move forward in areas where no other alternatives exist, the current literature has not fully 
considered the potential backsliding that opt-outs may produce. Although the current literature on differentiated integration calls attention to the possible second-order problems created by policy exemptions (Holzinger and Schimmelfennig 2012: 299), these problems have yet to be systematically analysed. Opt-outs can be a desired mechanism in cases when they enable the majority of the actors to escape compromises at the lowest common denominator by providing certain exceptions to the others. A multi-speed Europe allows those who favour European solutions to go forward and those who prefer the national status quo to stay behind. However, the use of opt-outs by several member states in a particular area can also lead to suboptimalities with regard to the outcome of European-level decision-making. Hence, one of the potential unintended consequences of providing opt-outs in politically sensitive areas is that increased differentiation challenges the fundamental idea of European integration, de facto leading to the decline of integration. The adoption of opt-outs, exemptions and other special rules to retain the compliance of one member state may develop its own expansive logic, creating an opt-out spiral wherein other member states claim similar arrangements. The opt-out thus gradually expands from a specific arrangement to common practice and from being a special rule to a more general feature of community legislation. ${ }^{4}$ In that case, the balance tips. The opt-out then transforms from being something that overcomes a policy deadlock into a counterproductive feature of collective decisions.

In this sense, instead of an onward move toward further integration, a specific output at $\mathrm{T}_{0}$ may initiate a logic of variation with unintended consequences and lock-in effects created by the opt-out mechanism. Allowing one actor a special rule of regulation to overcome a policy deadlock introduces new policy options for the other

\footnotetext{
${ }^{4}$ On the gradual expansion of 'special rules', see Martinsen and Falkner 2011.
} 
member states to consider at $T_{1}$ as well. As a result, an unintended process of emulation may be set into motion, with dynamic regulatory effects for the outcome of the policy process. In this scenario, the output at $\mathrm{T}_{2}$ has a causal link back to the collective decision at $\mathrm{T}_{0}$, when concessions were made to bring the difficult member state on board, but the regulatory output at $\mathrm{T}_{2}$ is one of increased variation instead of greater uniformity.

The analytical findings below identify a causal logic that leads to further differentiation. The causal dynamic runs as follows: an opt-out is initially granted because of the consensus norm in Council decision-making and the attempt to bring everyone 'on board'. The opt-out granted to the UK in isolation serves as a point of emulation for the other member states. The case law of the Court furthermore urges other member states to request the opt-out. This creates an opt-out spiral. A logic of variation with broad implications for the state of a social Union results.

\section{Data and Methods}

In our study, we use the method of process tracing to provide a single case analysis of EU regulation of working time between 1987 and 2012 and to establish causality in a process of differentiation (George and Bennett 2005: 205 ff.; Beach and Pedersen 2013). As one of the most suitable methods for conducting within-case analyses, process tracing takes a straightforward causal relationship from the initial theory, deconstructs this relationship into sequences and examines each divergent step to demonstrate how the causal sequence unfolds over time (Hancké 2009: 66-68). In our study, these divergent steps are identified as $T_{0}, T_{1}$ and $T_{2}$. The empirical data for this study were collected as part of a larger comparative research project examining 
current inter-institutional dynamics in EU social policy. It consists of two main data sources: 1) documents on the EU legislative process were collected and analysed, ranging from original Commission proposals and key assessments, Council compromise texts, individual and common position papers, position papers of EP political groups, and EP compromise texts and committee reports to social partners' positions and statements. The documents include a number of confidential position papers and letters that the interview respondents chose to allow us to use to give us broader insight into the processes behind the official arenas of decision-making; and 2) A large number of qualitative interviews were conducted with key respondents, including Commission civil servants in the relevant units of the relevant General Directorates, Council experts (mainly from the national delegations who were acting as Council representatives in the Council working groups), and members of the EP (in particular, rapporteurs and shadow rapporteurs as well as their assistants) and finally key negotiators from the social partners and some national representatives. The interviews were conducted between September 2011 and July 2013.

\section{Regulating Working Time}

A close empirical study of the processes that surround the EU regulation of working time reveals that the upward transfer of market correction is no simple power shift from the national to the supranational level. Instead, it is a battlefield between EU institutions that do not always act jointly-i.e., individual member states with diverse positions and disagreeing social partners. The integration process is marked by power dispersion such that many key actors and institutions aim to influence how regulation of working time unfolds over time. 
As the analysis below demonstrates, such transfers of competencies can produce differentiation and cause the process to depart from a simple forward course of integration. Differentiation may have its own spurring logic, where integration is met by contestation, which furthers differentiation. EU working time regulation implies a logic of variation in which differentiation extends in a causal dynamic that unfolds over time across $T_{0}, T_{1}$ and $T_{2}$. The isolated position of the $U K$, combined with the consensus norm of the Council, is the cause of differentiation at $\mathrm{T}_{0}$. Subsequent legal integration, met by political contestation in an enlarged EU, constitutes the causal dynamics at $T_{1}$. The contestation of legal integration spurs differentiation in an opt-out spiral, producing suboptimal institutional output at $\mathrm{T}_{2}$.

In this process, the CJEU acts as a key player who disturbs the established status quo with controversial legal decisions. The EP pushes for reforms that will codify the Court's ruling. This is met with contestation. The European Commission acts much more reluctantly, siding with key players in the Council. The Council initially aims for consensus but is increasingly disturbed by the 'awkward' position of the UK. Finally, the social partners are called in to reform what the EU and national decisionmakers have been unable to do. Table 1 provides a simplified overview of actor positions with regard to upward transfer in the EU in the area of working time.

\begin{tabular}{|l|l|}
\hline \multicolumn{2}{|l|}{ Table 1: Actor Constellations in Upward Transfer } \\
\hline Pro-Upward Transfer; Integration & Resistant to Upward Transfer; Contestation \\
\hline EP & EC (complex role. Proposes departure from \\
Social partners (employee) & the case-law of the Court) \\
Some Council members (France, Sweden, DK) & Social partners (Business Europe) \\
CJEU & Some Council members (UK+15) \\
\hline
\end{tabular}




\section{$T_{0}$-The Cause of Differentiation}

Upon the adoption of the Single European Act in 1987, health and safety at work was introduced for the first time in the EEC Treaty by means of article 118A, which set out that measures could be adopted through qualified majority voting. In 1990, the Commission proposed a Working Time Directive based on article 118A. The UK, however, firmly opposed the choice of legal basis, arguing that working time was not a health and safety matter but rather an employment issue for which reason the correct Treaty basis was either article 100 or article 235 , both of which required unanimity (Lewis 2003: 116).

The UK protest on the legal basis was not accepted. Negotiations continued. Despite this defeat, the UK participated in Council negotiations, and many attempts were made to bring the UK on board by offering important concessions. The UK pushed for exemptions for some sectors, implying that the sectors of air, rail, road, sea, inland waterway, lake transport, sea fishing, other work at sea and the activities of doctors in training were exempt from EU working time regulations. Moreover, the UK was granted an opt-out from the 48-hour work week, laying down that workers on an individual basis could agree with their employer that the 48-hour ceiling did not apply to them (article 18 (b) (i)). In that way, the UK influenced the general output of negotiations in significant ways, although owing to the rule of qualified majority voting, the other member states could have chosen to ignore the viewpoints of one member state. Even in 1991, a sufficient qualified majority existed, but the Council continued negotiations for another two years, attempting to establish consensus and bring 'everyone on board' (Lewis 2003: 118). 
The opt-out, exemptions and derogations inserted into the texts meant that, from the beginning, the working time rules became rather patchy. A compromise text was established that, from the beginning, the UK had influenced a great deal beyond what voting rules could account for. However, at this point, the opt-out was thought to be a delimited concession granted to bring the 'awkward partner' on board rather than a mechanism with its own dynamics. Working time was defined as 'any period during which the worker is working, at the employer's disposal and carrying out his activity or duties' and rest periods as 'any period which is not working time' (Art. 2 (1) and (2) of Directive 93/104/EC).

To the surprise of the other actors in the Council, the UK decided to abstain from the final vote (Beach 2001: 156). The abstention became one of a number of manifestations of the British member state against EU working time regulations. The point of departure for further differentiation had been created.

\section{$T_{1}$-Integration, contestation and the opt-out spiral}

Soon after the adoption of the Directive, the UK brought an annulment procedure before the CJEU, maintaining that article 118A was an inappropriate legal basis for the Directive. The CJEU did not, for the most part, support the UK's position, and it concluded that article 118A was the appropriate legal basis. ${ }^{5}$ The initial battles on working time were over, and additional transfer could take place. In 2000, the

\footnotetext{
${ }^{5}$ C-84/94 United Kingdom of Great Britain and Northern Ireland v Council of the European Union (1996) ECR I-5755.
} 
Directive was revised to bring the previously exempted sectors, except for seafarers, into it. ${ }^{6}$

Shortly after the revision, the new status quo of EU working time regulation was confronted with severe challenges by the European Court of Justice. The preliminary reference - 'SiMAP' — was sent to the European Court by the Spanish Trade Union of Doctors in Public Service and questioned whether on-call time for doctors was to count as working time. ${ }^{7}$ The CJEU established that doctors were not excluded from the Directive, although article 2 (2) of the framework directive allows for the exemption of public service activities that maintain public order and security. Furthermore, the Court set down that on-call time spent in a healthcare institution constituted working time within the meaning of the Directive, whereas on-call duty when the doctor did not have to be at the healthcare centre did not:

Time spent on call by doctors in primary healthcare teams must be regarded in its entirety as working time, and where appropriate as overtime, within the meaning of Directive 93/104 if they are required to be at the health centre. If they must merely be contactable at all times when on call, only time linked to the actual provision of primary healthcare services must be regarded as working time (CJEU conclusion in case C-303/98 SIMAP).

\footnotetext{
${ }^{6}$ Directive 2000/34/EC of the European Parliament and of the Council of 22 June 2000, amending Council Directive 93/104/EC concerns certain aspects of the organisation of working time to cover sectors and activities excluded from that directive.
}

\footnotetext{
${ }^{7}$ Case C-303/98 Sindicato de Medicos de Asistencia Publica (SiMAP) v Conselleria de Sanidad y Consumo de la Generalidad Valenciana. [2000] ECR 1-7963.
} 
The SiMAP ruling caused great political upset. In a joint letter sent to the Commissioner for Employment and Social Affairs from the British, Danish, Dutch and Swedish health ministers, the ministers emphasised their concern, writing:

The impact of the judgement on (all) our health systems could be to significantly reduce the availability and productivity of doctors. This may lead in some cases to the reorganisation and reduction of services, as more doctors or other practitioners will be required to staff the service (unofficial letter from "Health Ministers to Commission on WTD/SIMAP”).

The ruling went significantly beyond what the Council had agreed to include in the working time definition. It seems from the first responses that the SiMAP ruling was simply too controversial to address. Only a short number of weeks after the SiMAP decision, the Commission published a report that evaluated the implementation of the Working Time Directive. In this, the Commission only mentioned the SiMAP case briefly and did not much engage in the question of on-call time. The Commission's reluctance to bring in the new working time definition shows that, at that point, it did not want to challenge the member states and did not want to use the CJEU decision to extend the scope of European regulation. It had, however, known for a long time that on-call time was more generally disputed, at least from the time when the case was referred to the CJEU in 1998. This suggests that the Commission deliberately chose to ignore the judgment and not set fire to the political battles on working time. In addition, the German Federal Minister of Labour, Walter Riester, refused any general impact of the judgment, officially stating that, because the ruling addressed the 
Spanish system, it did not apply to Germany, even though the Spanish and German regulations were quite similar (Nowak 2008: 456).

The subsequent case of $\mathrm{CIG}^{8}$, however, repeated the conclusions of SiMAP. In 2003, the Jaeger case followed ${ }^{9}$. The Jaeger case was the next piece of legal integration to produce severe disturbance in the course of regulation. In this case, a higher German labour court asked the CJEU if time inactively spent on-call counted as working time even if the doctor was able to sleep during that time. Denmark, France, Germany, the Netherlands and the UK all delivered opinions in the case, sharing the viewpoint that time spent inactively on-call was not working time. In the hearings before the Court, the German government presented a very alarming economic impact assessment, saying that, if the Court confirmed the case law in the SiMAP case, staffing requirements would increase by $24 \%$ and between 15,000 and 27,000 additional doctors would have to be employed; the Germans estimated that the additional costs would come to EUR 1.75 billion. ${ }^{10}$ The Commission, on the other hand, held the opinion that on-call time was always working time because the employee had to be at the disposal of the employer. ${ }^{11}$ The Commission's opinion is interesting because it demonstrates that, at that point, it had accepted the CJEU's definition of working time in SiMAP. It did not, however, maintain this position, as is demonstrated below.

The CJEU's conclusions were largely a restatement of the SiMAP ruling, determining that on-call time for which the doctor had to be physically present at the hospital,

\footnotetext{
${ }^{8}$ C-241/99 Confederación Intersindical Galega (CIG) v Servicio Galega de Saúde (Sergas) (2001) ECR I-5139.

${ }^{9}$ Case C-151/02 Landeshauptstadt Kiel v Norbert Jaeger (2003) ECR 8389.

${ }^{10}$ See COM (2003) 843: 20 for this assessment.

${ }^{11}$ See the opinion of Mr Ruiz-Jarabo in Jäeger, para. 18.
} 
regardless of whether he or she could rest, was working time within the meaning of the Directive. From the Jaeger ruling, it was irrevocably clear that the inclusion of oncall time as working time applied generally, not specifically to the Spanish system as had previously been held by the German Minister of Labour. Despite the clear line of legal interpretation, many countries flouted the CJEU's conclusions and did not implement them (Financial Times 2005). Through this form of national disobedience, ignoring the case law of the Court, member states demonstrated that the course of integration was indeed contested.

In early 2004, the Commission followed up on the SiMAP and Jaeger rulings and sent out a communication as the initial step to revising the Working Time Directive. The Communication addressed the opt-out possibility in article 18 (1) (b) (i), which allowed for an individual agreement between employer and employee for the employee to work beyond the 48-hour work week. The Communication furthermore provided a dense impact analysis of the CJEU case law. The Commission recognised that the judgments of the Court had to be considered but did not establish the specific ways of how to do so. In the Communication, the Commission made clear that the Court decisions had extended the use of the opt-out. Before the SiMAP ruling, only the UK had made use of the opt-out. As a consequence of the SiMAP ruling, France, Germany, the Netherlands and Spain adopted the opt-out for the hospital sector. Luxembourg introduced the opt-out arrangement for hotels and catering. Furthermore, the Commission noted that, among the new member states, Malta, Cyprus and Slovenia had already adopted the opt-out possibility into their national legislation, and Estonia, Hungary, Latvia and Lithuania were expected to follow suit (COM 2003: 1516). The case law of the Court had thus caused an expansion of the opt-out from one 
member state to 13 , creating a considerable degree of differentiation in the application of the rules. An opt-out spiral had been created.

The European Parliament promptly reacted to the Commission's communication by means of a resolution. In the resolution, the EP criticised the Commission for being inconclusive as to how to move forward. The EP also called for the abolition of the individual opt-out possibility. It noted that the use of the opt-out had grown considerably within the UK and had spread to other member states. The EP emphasised that other member states had taken on the opt-out possibility to overcome the problems raised by the SiMAP and Jaeger decisions: 'It can therefore be said that use of the opt-out has been general rather than specific, under subjective rather than objective conditions and to an extent that exceeds practical requirements' (A50026/2004: 13).

\section{$T_{2}$-Differentiation and sub-optimality}

As a first attempt to revise the WTD, the Commission asked the social partners to enter negotiations and work out an agreement. However, the social partners declined to do so (COM 2004: 2), apparently because of the refusal of the European employer organisation UNICE (interview, social partners, August 2012). It was therefore up to the Commission to initiate a legislative process for revising the Working Time Directive. In September 2004, the Commission introduced its official proposal for amending the Working Time Directive. ${ }^{12}$ The Commission proposal marked a departure from the course of legal integration, and the case law of the Court was

\footnotetext{
${ }^{12} \mathrm{COM}(2004)$
} 
referenced only once. In fact, the Commission's proposal introduced a fundamental breach with established case law by distinguishing between 'on-call time' and 'inactive on-call time'. The new category 'inactive on-call time' was established as follows:

The inactive part of on-call time shall not be regarded as working time, unless national law or, in accordance with national law and/or practice, a collective agreement or an agreement between the two sides of industry decides otherwise. The period during which the worker carries out his activity or duties during on-call time shall always be regarded as working time (art. 2a of COM 2004, emphasis added).

In addition, the proposal maintained the opt-out possibility regarding the 48-hour work week but introduced the requirement that the opt-out had to be agreed upon in a collective agreement between social partners and not based on individual consent alone (COM 2004: 4, para. 12). However, when there was no collective agreement in place, individual consent would suffice. Furthermore, the Commission proposed extending the reference period for calculating the maximum weekly working time from four months to one year (COM 2004: 4, para. 14). In sum, the Commission's proposal departed from established case law and furthermore gave companies and member states greater flexibility in the organisation of working time. As such, the 2004 proposal represented a setback to the social rights that had evolved in the course of legal integration.

The Council of Ministers welcomed the distinction between 'in-active on-call time' and 'on-call time', claiming that it would introduce legal certainty. The Council also welcomed the extension of the reference period (Nowak 2008: 463). However, the 
member states disagreed on the questions of opt-out. France and Sweden were the most vocal advocates for ending the opt-out possibility, whereas Poland backed the UK on maintaining the right to exemption (Financial Times 2005).

The EP Committee on Employment and Social Affairs was responsible for the political examination of the proposal, and the position of rapporteur was held by the Spanish minister of the EP (MEP) from the S \& D group, Alejandro Cercas. ${ }^{13}$ The EP accepted all of the amendments as put forward by the rapporteur and thus established a strong cross-party consensus. From the first reading, the EP took a firm stand against the Commission's proposal and for other reasons, finding that it represented an unacceptable overturn of the Court's case law (EP Committee on Employment and Social Affairs 2005: 19). Furthermore, the EP strongly opposed keeping the opt-out possibility as well as extending the reference period. It found that the Commission had disregarded the EP's early opinion and that the entire proposal went in the opposite direction of what the EP had previously clearly stated as its preferences (EP report A6-0105/2005: 16-17).

Five years of negotiations followed within and between the two legislatures. Throughout negotiations, the EP stood firm on its call to eliminate the opt-out (Financial Times 2008). By the end of April 2009, the EP had definitively vetoed the Council compromise (Conciliation committee decision 2009). For the first time, the third reading conciliation procedure between the EP and the Council did not manage to establish agreement (interview, social partners, August 2012).

Essentially, the opt-out made an inter-institutional compromise between the EP and the Council impossible. The parliament's viewpoint was that the opt-out was a

\footnotetext{
${ }^{13}$ See report on the proposal from the EP Committee on Employment and Social Affairs (2005).
} 
temporary phenomenon, included as a temporary concession to one member state at a difficult time. According to the parliament, it was never intended to continue (interview, Commission 3 March 2012; interview EP, 29 March 2012). The Council, however, was internally divided on the issue. Some member states were willing to end it, and others to phase it out. However, for an increasing number of the Council's members, it had become a fundamental issue 'that they never intended would be other than permanent' (interview, Commission, 3 March 2012). This Council alliance insisting on the opt-out had been further strengthened by enlargement. A considerable number of the new member states, including Cyprus, Estonia, Malta and Bulgaria, took the same approach as the UK and adopted an opt-out that applied across all sectors. Other new member states - the Czech Republic, Hungary, Latvia, Poland, Slovakia and Slovenia — had demanded an opt-out of more limited use that would be restricted to specific sectors, especially healthcare. In addition, Germany, Belgium, France, the Netherlands and Spain had opt-outs for some of their sectors (COM 2010a; COM 2010b: 84-99). Thus, from being a concession granted to one member state, the opt-out had developed into a rule that applied to a majority of the member states. This majority observed no reason to compromise on the opt-out, which allowed them to avoid what they considered to be the negative consequences of the Court's case law. The opt-out became the reason the EP and the Council were not able to reach a compromise in the conciliation committee. Differentiation had gradually expanded into shielding the majority of member states from the main principle of EU working time regulations.

The long-lasting political negotiations had failed, and despite five years of dialogue, bargains and concessions, no solution was found and no reform of the Directive was adopted. A solution to the on-call problem was, however, still strongly demanded 
(Financial Times 2009). In March 2010, the Commission restarted the process of revising the Working Time Directive by consulting the European social partners.

Eighteen months later, in November 2011, the European social partners declared that, this time, they were willing to negotiate in accordance with the social consultation procedure provided for in Articles 154 and 155 of the Treaty on the Functioning of the European Union (TFEU). Business Europe ${ }^{14}$ had changed its position and now accepted the Commission's invitation, in part because a clarification to the case law was broadly requested but also because both sides of the social partners had an interest in revitalising the 'corporatist policy community' from the 1990s that had successfully concluded European collective agreements on labour law issues ${ }^{15}$ (interview, social partners, August 2012; Falkner 1998; Martinsen and Falkner 2011: 131-133). The social partners initiated their negotiations in late 2011. The first meeting was held on 8 December 2011. The first half-year primarily addressed agreeing on what was open to negotiation (interviews, social partners, March 2012, November 2012). The Commission agreed to extend the initial first 9 months that had been granted for negotiations to 31 December 2012, 'given that their negotiations are making progress' (Commission press release 2012). However, the timeframe was tight and disagreements paramount. ETUC ${ }^{16}$ conducted the negotiations on behalf of the European employees, and the employer side was represented by Business Europe, with $\mathrm{CEEP}^{17}$ representing the public-sector employers and $\mathrm{UEAPME}^{18}$ representing

\footnotetext{
${ }^{14}$ In 2007, the European Employers' organisation UNICE changed its name to Business Europe.

${ }^{15}$ In the 1990s, three legally binding collective agreements were concluded that were implemented in directives: parental leave in December 1995, part-time work in June 1997 and fixed-term work in March 1999 (Martinsen and Falkner 2011: 133).

${ }^{16}$ The European Trade Union Confederation

${ }^{17}$ European Centre of Employers and Enterprises providing Public services.
} 
the employers from small and medium-sized enterprises. Although the employers formally agreed to also bring the opt-out into negotiations, in reality this was not an option because an agreement still had to be incorporated into a Council Directive, and the partners knew that the UK would do its utmost to block such a result (interview, social partners, June 2013). Although ETUC and CEEP largely concurred on the need to establish an agreement, Business Europe blocked progress in negotiations. The main disagreements were about the definition of working time and the opt-out (interviews, social partners, June 2013, July 2013). After an executive committee meeting on 5-6 December 2012, ETUC made it clear that it did not wish to continue negotiations. The social dialogue on working time had failed, and the latest attempt to revise the suboptimal text on EU working time could not overcome the policy deadlock and reduce differentiation.

\section{Implications of differentiation in EU working time regulations}

Whereas differentiation at $\mathrm{T}_{0}$ had allowed integration to proceed for the large majority of member states, it gradually expanded sub-optimality to the extent that an increasing number of member states departed from the general rule. Examined over time, the effects of the opt-out extended much beyond the isolated incident at $\mathrm{T}_{0}$, when the UK won its concessions and the consensus norm of Council negotiations was maintained. Over time, such differentiation produced a logic of variation, where the opt-out possibility was generalised from the one to the many to avoid the impact of the Court's case law. The exception had become the general rule:

\footnotetext{
${ }^{18}$ The European Association of Craft, Small and Medium-sized Enterprises.
} 
And the problems with the opt-out is that of course the ruling has created a situation where countries to be able to cope had to introduce the opt-out, although they hadn't introduced the opt-out before, like Germany for instance, or many other countries. (...) The opt-out was not a subject matter for the case law because the ruling was only about on-call, but it was the increasing recourse to the introduction to the opt-out was the direct consequence of the ruling of the on-call time (interview, social partners, July 2013).

Legal integration was met with contestation and came to extend differentiation. The suboptimal regulatory system that was generated had severe consequences for implementation and compliance within the field of working time regulation, such that no member states will likely comply with the Directive as it has developed in light of the Court's interpretations (interviews, social partners, November 2012; January 2013; June 2013; July 2013). It is also expected that more member states will request the opt-out in the future to avoid the case law (interview, social partners, January 2013). This implies that EU working time regulations resemble 'an emmentaler where the holes are bigger than the cheese' (interview, social partners, March 2012). The economic and social effects of increased differentiation are held to be significant because they bring competitive advantages, even as they damage the health and safety of workers, to those member states where workers can work beyond the 48-hours work rule (interviews, social partners, January 2013, June 2013). Thus, differentiation has effects on those member states that opt for more peripheral integration, but it also has consequences for those that remain in the core as it becomes increasingly impossible to revise the directive and ensure its compliance. The logic of variation that was created has broad implications. Exceptions have become the general rule, 
with important consequences for implementation, compliance and legitimacy for both the core member states and the periphery.

\section{Conclusion}

EU integration is increasingly being characterised by differentiation. In a European Union of heterogeneity and ample functional scope, both the core member states, who want to move forward, and the periphery, who wish to stay behind, are calling for more flexibility in supranational legislation. However, as this paper has demonstrated, allowing for differentiation to overcome a joint decision trap has dynamic and broad implications that are likely to produce a decline of integration over time. When one member state has embarked on the path to differentiation, it offers similar opportunities to fellow member states. CJEU litigation does not necessarily strengthen integration, but it may amplify the logic of variation as in the present case, in which more member states request the opt-out to shield themselves from the impact of the Court. Whereas the opt-out is a short-term solution for the EU member states in managing upward transfer, its effects are far-reaching, leading to the decline of integration and sub-optimal policy outcomes.

In the recent literature on European integration, a multi-speed Europe is introduced as a possible way to avoid not only deadlocks in decision-making but also potentially the democratic deficit of the EU. The argument holds that the possibility of granting member state exceptions on politically sensitive matters would provide the EU with both a better functioning and a more legitimate legislative process (Scharpf 2006: 856-861). However, our analysis shows that the introduction of the opt-out might in fact have had the very opposite effect of that intended. As the case of working time 
regulation reveals, the introduction of opt-outs can inspire numerous member states to demand and introduce this option in a variety of ways. As a result of the spiralling of opt-outs and the uneven implementation record across member states, the outcome of regulation becomes increasingly suboptimal. When a European rule only applies to some in full and to others in parts, heterogeneity increases. Differentiation affects those member states that place themselves on the periphery. They gain a competitive advantage over member states that apply the regulation in full. At the same time, optouts have social consequences, as in the present case in which EU social rights differ across member states. Differentiation also affects the remaining member states in the core because additional integration becomes increasingly difficult when those on the periphery insist on maintaining their exceptions. Because exceptions are difficult to reverse, they generate sunk costs and lock-in effects as well.

Uneven rules create uneven implementation. Implementation comes to differ considerably across member states, ultimately affecting compliance. Over time, differentiation is no longer an isolated solution to bringing the 'difficult' on board but becomes a cause with dynamic effects. It serves as a point of emulation for other member states, thus creating a logic of variation with lock-in effects for the further path to differentiation. Integration theories are generally ill-equipped to explain these discrepancies, for decades focusing on when and why integration takes place and overlooking the cases in which it does not. However, in a union of increased heterogeneity and contested upward transfer, responsive integration theories are called for that will be equally capable of explaining the logic of variation as well as the forward moves.

Word count: 7857 words 


\section{Acknowledgements}

Financial support from the Danish Research Council project no. 10-079675/FSE is gratefully acknowledged. We would like to thank Rebecca Adler-Nissen, Jørgen Grønnegaard Christensen, Caroline Grøn, Christel Koop, Mads Dagnis Jensen, Kalypso Nicolaïdis, Ian Manners, Ben Rosamond, Michael Tatham and Marlene Wind for most valuable comments on earlier drafts of this manuscript. A special thanks goes to the two anonymous reviewers for their most constructive comments and enabling critique. 


\section{References}

Adler-Nissen, R. (2008) 'The diplomacy of opting out: a Bourdieudian approach to national integration strategies', Journal of Common Market Studies 46(3): $663-84$.

Adler-Nissen, R. (2011) 'Opting out of an ever closer union: the integration doxa and the management of sovereignty', West European Politics 34(5): 1092-13.

Beach, D. (2001) Between Law and Politics: The Relationship Between the European Court of Justice and EU Member States, Copenhagen: Djøf Publishing.

Beach, D. and Pedersen, R. (2013) Process Tracing Methods: Foundations and Guidelines. Ann Arbor: University of Michigan Press.

Dyson, K.H.F. and Marcussen, M. (2010) 'Transverse integration in European economic governance: between unitary and differentiated integration', Journal of European Integration 32(1): 17-39.

Falkner, G. (1998) EU Social Policy in the 1990s: Towards a Corporatist Policy Community, European Public Policy Series, London: Routledge.

Falkner, G. (2011) 'Introduction: the EU's decision traps and their exits', in G. Falkner (ed.), The EU's Decision Traps. Comparing Policies, Oxford: Oxford University Press, pp. 1-17.

George, A. and Bennett, A. (2005) Case Studies and Theory Development in the Social Sciences, Cambridge, MA: MIT Press.

Hancké, B. (2009) Intelligent Research Design. Oxford: Oxford University Press.

Holzinger, K. (2011) 'Environmental policy in the joint-decision trap? The critical balance between "market making" and "market correcting", in G. Falkner 
(ed.), The EU's Decision Traps. Comparing Policies, Oxford: Oxford University Press, pp. 110-27.

Holzinger, K. and Schimmelfennig, F. (2012) 'Differentiated integration in the European Union: many concepts, sparse theory, few data', Journal of European Public Policy 19(2): 292-305.

Jensen, M.D., Koop, C. and Tatham, M. (2014) 'Coping with power dispersion? Autonomy, coordination, and control in multi-level systems', Journal of European Public Policy [PUBLISHER TO UPDATE DETAILS AT PROOF].

Lewis, J. (2003) 'Institutional environments and everyday EU decision making: rationalist or obstructivist?', Comparative Political Studies 36(1/2): 97-124.

Leuffen, D., Rittberger, B. and Schimmelfennig F. (2013) Differentiated Integration: Explaining Variation in the European Union, London: Palgrave Macmillan. Martinsen D.S. and Falkner, G. (2011) 'Social policy: problem solving gaps, partial exits and court-decision traps', in Falkner G. (ed.), The EU's Decision Traps. Comparing Policies, Oxford: Oxford University Press, pp. 128-45.

Nowak, T. (2008). 'The working time directive and the European court of justice', Maastricht Journal of European and Comparative Law 15(4): 447-71.

Pierson, P. (1996) 'The path to European integration: a historical institutionalist analysis', Comparative Political Studies 29(2): 123-63.

Pierson, P. (2000) 'Increasing returns, path dependence, and the study of politics' American Political Science Review 94(2): 251-68.

Scharpf, F.W. (1988) 'The joint-decision trap: lessons from German federalism and European integration', Public Administration 66(3): 239-78. 
Scharpf, F.W. (2006) 'The joint-decision trap revisited', Journal of Common Market Studies 66: 239-78.

Trauner, F. (2011) 'Increased differentiation as an engine for integration? Studying justice and home affairs', in G. Falkner (ed.), The EU's Decision Traps. Comparing Policies, Oxford: Oxford University Press, pp. 145-62. 